\title{
African-American Male Business Students' Perspective Of Academic Advising: A Retention And Success Strategy
}

Siavash Abghari, (E-mail: sabghari@morehouse.edu), Morehouse College

\begin{abstract}
Academic advising is an essential component of any institution of higher education. Advisors and advisees work together to make an individual academic plan based on each student's weaknesses, strengths, and goals. The advising relationship is an on-going communication that transcends course selection and should attempt to assist students as they explore the breadths of the curriculum, experience college life, focus on a major concentration, and prepare for life after graduation. In order to improve advisement in the Business Administration Program at a Historically Black College, a questionnaire was developed and administered in various classes within the Program. The purpose was to identify possible weaknesses in academic advising and make necessary changes and adjustments to better serve the students' needs and enhance retention and institutional effectiveness. This study identifies and indicates that students are significantly dissatisfied with the current advisement system in the Business Program at the College. Based upon findings of this investigation, recommendations are made to improve the advisement system.
\end{abstract}

\section{INTRODUCTION}

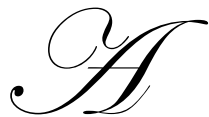

$\mathrm{s}$ an institution of higher education, College faces many challenges to attract and retain AfricanAmerican male students. For example, the participation of African-American male high school graduates was about 35 percent in 1997 and for female African-American was 43.6 percent. For example, among African-American high school students who graduated in 1997, only 35 percent of males and 43.6 percent of females went on to attend college. According to the U.S. Department of Commerce, as of 1997, only 14.4 percent of African-American adults, ages 25 to 29, held a bachelor's degree or higher. For African-American men, this was 12.1 percent, compared with 27.8 percent for all young adults. The college completion rate for AfricanAmerican men was 34 percent in 1997, compared with 65 percent for Asian-American students and 58 percent for white students (Jones 2001). In addition, in the late 1970s, the majority of African-American college students were enrolled at historically black colleges and universities (HBCUs). By the late 1980s, this trend was reversed and more African-American students were attending predominantly white institutions than HBCUs (Green 2001).

To face the challenge of attracting students from a declining pool of African-American males graduating from high school and retaining them until they graduate from College, first, as an institution of higher education, we must educate ourselves to better understand the expectations and needs of the students in order to make necessary institutional programmatic changes. We need to provide a climate for student development and seek strategies that will help us in our retention initiatives and institutional effectiveness. At the College in this study, little attention has been focused on the need for our college to change and adjust to the students it serves. The objective of this study is to investigate the business students' perspective on advisement and changes that the Business Program needs to make to serve the students and improve their satisfaction.

Student advising is an integral part of support services for student learning and development. Many students, faculty and staff behave as if the only objective of academic advising is to assist with course registration and nothing more than a bureaucratic detail. In this study, we try to understand students' perspective of academic 
advisement, identify the shortcomings of the current advisement system in the Business Program, and then make recommendations to improve developmental student advising and retention. In the Business Program there is an advisement committee composed of nine faculty; as students enter into the program, they are assigned to an advisor alphabetically. As a liberal arts and an HBCU institution with the legacy and continued commitment to develop leaders with academic knowledge, skills, critical thinking, social responsibility, civic and political responsibility, moral and ethical responsibility, self-awareness and personal values, spirituality and physical well-being, all

dimensions of student development are very important. A holistic student development is the core of the mission of the College. Therefore, it is important to provide students with an effective advisement system first.

\section{LITERATURE REVIEW}

Studies by researchers indicates that a new look at advising in the institutions of higher education is needed in order to serve the diverse needs of students and make these institutions more effective in developing students. Academic advising by faculty is linked to student involvement and persistence in College. Colleges that make students more involved more effectively influence learning and student development. Student involvement includes the investment of time and energy to studying, participating in student organizations, and interacting with faculty and other students (Astin 1984). Studies also indicate that more informal quantity and quality contact with faculty, especially contact focusing on intellectual or career-related issues, increases students' involvement, motivation, academic achievement and satisfaction with the College and their institutional persistence (Pascarella 1980, 1985; Terenzini, Pascarella, and Lorang 1982). High levels of academic and social integration of students leads to high student retention (Tinto 1987; Tinto, 1993). Learning is another contributing element to retention. When students learn more, they find more value in their educational experience, and they are more likely to finish their degree program (Tinto, 2003). Holistic student development is the core of the mission of many institutions of higher education. A theoretical base of a holistic view of student development is proposed in a 4C schema--culture, curriculum, co- curriculum, and community (Braskamp, Trautvetter, Ward, 2006). Inadequate and poor academic advising is the second important factor in student attrition after the amount of financial aid available. These results can be important to advisers, for advisors have the capacity to increase meaningful contact with students and to encourage them to persist in college.

\section{METHODOLOGY}

A comprehensive questionnaire to evaluate the Business Program was developed; a section of this questionnaire deals with advisement. Students are asked about the quality of advisement, level of satisfaction, importance of meeting their advisor, students' preference in choosing their advisor, peer advisement and if they meet with their advisor on a regular basis. The purpose is to identify possible weaknesses in academic advising and make necessary changes and adjustments to better serve the students' needs and enhance retention and positive outcomes. Survey instruments were administered in different classes in the Division of Business Administration.

\section{DISCUSSION AND RESULT}

One essential way to engage students in advising is to design programs that acknowledge their individual needs. Diversity not only characterizes today's student population, but also contributes to a pluralistic society that benefits all members of the college community. Because advisers can encourage students to explore their differences as positive factors, the advising relationship can be particularly responsive to pluralism. Developmental advisers involve students in the advising relationship and demonstrate that circumstances surrounding individual differences, not stereotypical differences, define students' needs. The system that maintains status quo must be challenged in order to make needed improvement.

The data reported in this section are based on a sample of 468 business administration students, which is about 49 percent of total students in the field at the College. First the students were asked if they meet with their advisor on a regular basis. The percentage of students meeting their advisor was $23.88 \%$; $65.88 \%$ indicated that they do not meet their advisor on regular basis, and $10.24 \%$ did not respond to this question. In the next part, students were asked to rate their satisfaction with their advisor's availability, knowledge of academic requirements in major, 
knowledge of general education requirements, assistance in planning an academic program, overall quality of academic advising and overall quality of career advising, by checking one of the following possible responses: 1) Very Satisfied, 2) Satisfied, 3) Neutral, 4) Dissatisfied, 5) Very Dissatisfied.

Students' responses and our findings are summarized in Table 1. As we see in the Table, with regard to advisors' availability, 13.86 percent state they were dissatisfied, and 12.79 percent were very dissatisfied. A total of 27 percent of respondents were dissatisfied or very dissatisfied, compared with 37 percent satisfied and very satisfied.

Table 1: Students Perspective of Academic Advising

\begin{tabular}{|c|c|c|c|c|c|c|}
\hline$\Downarrow \mathrm{N}=468$ & $\begin{array}{c}\text { Availability of } \\
\text { faculty advisor }\end{array}$ & $\begin{array}{c}\text { Faculty } \\
\text { advisor's } \\
\text { knowledge of } \\
\text { academic } \\
\text { requirements in } \\
\text { my major }\end{array}$ & $\begin{array}{c}\text { Faculty } \\
\text { advisor's } \\
\text { knowledge of } \\
\text { general } \\
\text { education } \\
\text { requirements }\end{array}$ & $\begin{array}{c}\text { Faculty } \\
\text { advisor's } \\
\text { assistance in } \\
\text { planning my } \\
\text { academic } \\
\text { program }\end{array}$ & $\begin{array}{c}\text { Overall quality } \\
\text { of academic } \\
\text { advising }\end{array}$ & $\begin{array}{c}\text { Overall quality } \\
\text { of career } \\
\text { advising }\end{array}$ \\
\hline Very satisfied & $15.78 \%$ & $18.55 \%$ & $17.27 \%$ & $17.70 \%$ & $15.78 \%$ & $14.29 \%$ \\
\hline Satisfied & $21.32 \%$ & $21.11 \%$ & $20.47 \%$ & $21.11 \%$ & $18.98 \%$ & $16.42 \%$ \\
\hline Neutral & $11.73 \%$ & $15.99 \%$ & $16.84 \%$ & $17.91 \%$ & $15.35 \%$ & $14.29 \%$ \\
\hline Dissatisfied & $13.86 \%$ & $13.43 \%$ & $13.22 \%$ & $12.58 \%$ & $13.22 \%$ & $11.94 \%$ \\
\hline Very & $12.79 \%$ & $12.37 \%$ & $14.29 \%$ & $11.94 \%$ & $12.15 \%$ & $13.86 \%$ \\
\hline dissatisfied & $24.52 \%$ & $18.55 \%$ & $17.91 \%$ & $18.76 \%$ & $24.52 \%$ & $29.20 \%$ \\
\hline No response & $100 \%$ & $100 \%$ & $100 \%$ & $100 \%$ & $100 \%$ & $100 \%$ \\
\hline Total & & & & & 100 \\
\hline
\end{tabular}

As is indicated, a major source of student dissatisfaction is availability of the faculty advisor. Faculty should be trained and encouraged to be more sensitive to the needs of students. More meaningful contact between faculty and students will enhance students' involvement and motivation, which results in persistence, retention and a higher graduation rate (Astin 1984). To improve students' satisfaction, advisors should be made more accessible. More faculty and preferably all faculty instead of a selected few in the Department should participate in advisement, and students should be able to choose and change their advisor. One of the problems faced in the advisement system is the advisor/student ratio. In the program under study the average advisor load is about 120 students, which is very high for instructional staff. The expert opinion concerning advisor load is 300/1 for full-time advisors and 20/1 for full-time instructional staff (Habley, 2004).

With respect to faculty advisor's knowledge of academic requirements in their major program, 18.55 percent state they were very satisfied, 21.11 percent were satisfied, 15.99 percent were neutral, 13.43 percent dissatisfied and 12.37 percent very dissatisfied. Another source of dissatisfaction of the students with the advisement program is the faculty advisor's knowledge of academic requirements in the business program.

In addition to academic requirements in the major program, students must meet the College General Education requirements for completion of their degree. Faculty advisors' knowledge of General Education requirements is another source of student dissatisfaction. A total of about 28 percent of respondents were dissatisfied or very dissatisfied and about 17 percent neutral, compared with about 38 percent satisfied and very satisfied. To improve students' satisfaction, development and their retention, advisors need to be trained and be more informed about academic and general education requirements.

The students were also asked to respond and express their level of satisfaction with respect to the assistance received from their advisors in planning their academic programs and the quality of advisement regarding academic and career issues. The same pattern of dissatisfaction and satisfaction is observed with regard to these issues and the previous issues considered. 
Then students were asked about the primary reason for not meeting their advisor. Among them, 32.20 percent indicated that they don't find it necessary, 20.90 percent expressed they don't have time to meet with their advisor, 17.91 percent don't find their advisor helpful and 28.99 percent cited other reasons.

Then they were asked if you were to meet an advisor, which academic or career advisement would you find more important? Academic advisement was more important to 14.29 percent of respondents, career advisement to 12.58 percent, 58 percent indicated both are equally important and 15.13 percent stated other reasons.

Students were asked you they talk to about advisement. 33.05 percent of students indicated they go to other faculty, 38.38 percent get advisement from other students and friends, 11.51 percent go to career services, 9.81 percent don't go to anyone and 7.25 percent indicated others.

Next participants were asked if they preferred to have more of a say in who their advisor is. 47.55 percent prefer to choose their advisor, 10.45 percent said no, 21.96 percent expressed no preference and remained indifferent, and 20.04 percent did not respond.

Then students were asked if they have used peer advisement. Among participants, 56.93 percent indicated that have obtained peer advisement, 37.10 percent said no and 5.97 percent provided no response. Finally, 31.77 percent of the student respondents indicated they find peer advisement very helpful, 27.51 percent find it helpful, 18.98 percent somewhat helpful, 13.01 percent not helpful and 8.73 percent did not respond this question.

\section{CONCLUSIONS AND RECOMMENDATIONS}

Faculty advisors are very important in helping institutions of higher education to retain students by helping students to achieve their educational and developmental goals. This can be achieved if there is an institution-wide commitment and shared responsibility. Academic advising is a shared responsibility of students, faculty, staff and the College. Students are responsible for making their own decisions based on the best information and advice available to them and their best judgment. They are responsible for arranging and preparing for advising meetings and understanding degree and program requirements. Faculty is responsible for monitoring the academic progress of their advisees, making appropriate referrals to other campus offices, and communicating clearly to their advisees. The College is responsible for providing appropriate recognition for the role that faculty play in the advising system, assuring that there are clear policies, procedures, and resources to support the advising process, assisting faculty to develop effective advising skills, and conducting ongoing assessment of the advising program.

This study indicates that there is a significant dissatisfaction with the current advisement system in the Business Program at the College. Most of the students are advised about the courses of study in the Business Program, but academic advisement is not viewed as a means of enhancing faculty/student contact, student involvement, student persistence and student success and retention. It should be noted that about one third of the total student population at this institution, are business majors and improvement of the advisement program has great impact on students' satisfaction and institutional effectiveness. Also, research shows that increasing student retention through improved advising has fiscal benefits for the institution in the form of tuition revenue, money generated from increased residency in dormitories and meal plans, and ticket sales for various games and concerts (Glennen 2003).

To engage students in academic advising as a means to help the institution in achieving its mission and enhance the positive outcomes of the College, an advising program should be developed that recognizes the individual needs, desires and aspirations of students, one that is based on shared responsibility. Students are very diverse in regard to their social and financial background. Among students participating in this study, about 73 percent were working part-time, 11.30 percent had a full-time job, and 76 percent were receiving financial aid. 
It is clear from the students' perspective that the current advisory framework is not satisfactory. An advisory system is recommended which is based on shared responsibility and framed for continuous change to improve students' development, success, retention and institutional effectiveness of the College. In order to achieve this, the following is recommended:

1. Frame an advisement system based on total full time faculty participation and centered on students' development and success. Total faculty participation will improve the advisor load and advisor accessibility significantly.

2. Conduct an advisement training for the faculty to emphasis the importance of advising in students' development. In this training, provide information about program requirements, activities, student involvement, establishing goals, expectations and strategies for academic success, and career guidance. These professional development workshops should cover conceptual, relational and informational skills.

3. Conduct an ongoing evaluation of the advisement program and advisors with feedback from students in order to get direction for change.

4. Make the advisement system flexible, so that students can choose or change their advisor if they desire.

5. Recognize and reward the contribution of faculty advisors.

6. Develop an outreach or intrusive advising practice. This is an advising system based on the philosophy that students should receive advisement throughout the academic year, as it is necessary not once a semester or a year. More frequent, meaningful, and one to one faculty student interaction is the most important determinant of undergraduate student satisfaction (Astin 1985).

7. Assure that there are clear procedures, policies, and resources to support the advising process.

\section{REFERENCES}

1. Astin, A.W., 1984. Student Involvement: A Developmental Theory for Higher Education. Journal of College Student Personnel 25, 298-307.

2. $\quad$ Astin, A. W., 1985. Achieving Educational Excellence. San Francisco, CA: Jossey-Bass.

3. Braskamp, L. A., Trautvetter, L.C., Ward, K., 2006. Putting Students First, How Colleges Develop Students Purposefully. Anker Inc. Bolton, Massachusetts

4. Glennen, R. E., 2003. The Importance of Faculty Advising: A CEO and CAO Perspective, in Faculty Advising Examined, edited by Gary 1. Kramer, 2003, pp. 40-54

5. Green, P.E., 2001. The policies and Politics of Retention and Access of African-American Students in Public White Institutions, in Retaining African Americans in Higher Education, edited by Lee Jones 2001, p.46

6. Habley, W. R. (2004). Advisor Load. Retrieved from the NACADA Clearinghouse of Academic Advising Resources Web site: http://www.nacada.ksu.edu/Clearinghouse/AdvisingIssues/advisorload.htm

7. Jones, Lee, 2001. Creating an Affirming Culture to Retain African-American Students During the Post affirmative Action Era in Higher Education, in Retaining African Americans in Higher Education, edited by Lee Jones, Stylus, Sterling, VA. 2001, pp.3-20

8. Pascarella, E.T. 1980. Student-Faculty Informal Contact and College Outcomes. Review of Educational Research 50, 545-95.

9. Pascarella, E. T., 1985. College Environmental Influences on Learning and Cognitive Development. In Higher Education: Handbook of Theory and Research, vol. 4, edited by J.C. Smart. New York: Agathon Press.

10. Terenzini, P.T., Pascarella, E.T. and Lorang, W.G. 1982. An Assessment of the Academic and Social Influences on Freshman Year Educational Outcomes. Review of Higher Education 5: 86-109.

11. Tinto, V. 1987. Leaving College: Rethinking the Causes and Cures of Student Attrition. Chicago: Univ. of Chicago Press.

12. Tinto, V., 2003. Establishing Conditions for Student Success, in Improving Completion rates Among Disadvantaged Students, edited by Liz Thomas, Michael Cooper and Jocey Quinn 2003, pp.1-9 


\section{NOTES}

